\title{
Tadeusz Borutka
}

ORCID: https://orcid.org/0000-0002-8326-0726

The Pontifical University of John Paul II in Krakow, Poland

\section{Caring for the Person and the Human Family as a Priority for the State and the Church}

\begin{abstract}
Caring for the person and the human family is one of the most important tasks for the State and the Church. In contrast to the activities of the civil society, the work of the Church in this area is called a specific work, because it requires the use of so-called poor means, i.e. peaceful means. From the very beginning, the teaching of the Church has stood and stands on the ground of Christian personalism. The Church looks at marriage and family in the same spirit. It views the family as the basic and irreplaceable community. It is the family that offers the most effective tools for the humanization and personalization of society. Any social and family policy should serve this end. The Church should follow a similar policy. However, the pastoral concern of the Church is not limited only to Christian families. It should manifest itself in relation to all families and especially those who face difficult or abnormal situations.
\end{abstract}

\section{Keywords}

God, marriage, family, upbringing, development, progress, state, Church.

Contemporary person lives in the age of major technological, economic and cultural progress. Human beings are increasingly in control of nature and have gained extensive knowledge of laws governing social relations. Human solidarity is growing. The growing reservoir of information multiplies human's creative capabilities and gives him/her access to the intellectual and cultural heritage 
of other peoples. New means of communication facilitate the exchange of ideas. The findings of biology, psychology and social sciences make it possible for man to go deeper into the riches of his own being.

Despite this amazing development and progress, there are also increasing difficulties. It can be said that the current image of the world shows "deep shadows" and an imbalance. The crisis of civilization has become a topic which comes up more and more frequently. It is primarily the crisis of truth, which is related to the crisis of such notions as "love", "freedom", or even the "person." This crisis is visible in economic, social and political life at both national and international levels. People live in deep anxiety. They are afraid that they might be deprived of their right to freedom and truth, as well as the right to profess their faith and be guided by their own conscience in everyday life. They are becoming increasingly concerned about their own lives and the lives of their families. ${ }^{3}$

This is because the family itself is experiencing multiple internal crises. It is exposed to harmful cultural, social and economic influences, which not only weaken its cohesion, but also make it harder to start a family and hinder its functioning. ${ }^{4}$ The family is at risk of losing the truth about itself. The trend of postponing the time of entering into marriage is another worrying phenomenon, which indirectly affects the growing percentage of informal relationships. Unfortunately, many families have been influenced by these factors, which often results in their breakdown. Nowadays, family ties are becoming limited to two generations. This process is fostered by housing difficulties, especially in big cities. In many social circles, there is the temptation to refrain from having children. This fact is perceived through the lens of numbers and statistical reports. At the same time, contraception and abortion are being promoted. ${ }^{5}$

This complicated state of affairs has made people look for effecting ways of getting out of this dangerous situation. They try to assess their situation, hoping that this diagnosis will lead to them some conclusion. This is where the Church comes to their aid. The teaching of the Church addresses all social

'Cf. P. Andre-Viencent, La doctrine sociale de Jean Paul II, Paris 1983, p. 24.

2 Gratissimam sane, 13.

${ }^{3}$ Cf. T. Borutka, Nauczanie społeczne papieża Jana Pawła II, Kraków 1994, p. 6.

${ }^{4}$ W. Bołoz, Promocja osoby w rodzinie, Warszawa 1998, p. 23.

${ }^{5}$ Cf. T. Borutka, T. Kornecki, P. Kroczek, Rodzina fundamentem społeczeństwa. Aspekt społeczno-prawny, Kraków 2018. 
issues. The Christian message of salvation concerns man as a whole, including his essence and actions, in both his personal life and on the social level. The vocation of the Church is to serve man and his salvation. The Church intervenes in social matters thus fulfilling its religious and moral mission. ${ }^{6}$

When the Church becomes involved in social matters, it is not limited to theoretical reflections, instructions, statements or reminders, but shows the basic standards and directives for actions, which every man of faith should consider the foundation of his actions and cooperation with other people. The social doctrine of the Church, which has been developing for the last few decades, shows that the fundamental need is to respect man and his dignity, as well as to take care of his family. In this respect, it is necessary for the state to get involved and cooperate with the Church.

\section{The specific character of the social teaching of the Church}

Contrary to the functioning of the civil society, the activity of the Church on the social level is referred to as specific action ${ }^{7}$.This is because this activity is not political, economic or technical. The Church is not competent in technology or politics. Its activity does not involve measures used by political systems or political authorities. ${ }^{8}$

The specific character of the contribution made by the Church to the social field requires the use of so-called poor measures, that is peaceful measures. ${ }^{9}$ It was Christ himself who taught the Church to use such measures. They are appropriate for the evangelical mission of the Church. This is what John Paul II said about their value and efficiency to the representatives of the Diplomatic Corps on 12 January 1979: "In this age of enormous progress of the rich means at the disposal of the present-day political, economic and civic structures, these specific means of the Church retain all their meaning, keep focus of their goals,

\footnotetext{
${ }^{6}$ R. Antoncich, J. M. Munarriz, La doctrine sociale de l'Eglise, Paris 1992, p. 16.

${ }^{7}$ Jan Paweł II, Nowy świat powstać musi w imię Boga i człowieka. Do budowniczych społeczeństwa pluralistycznego, „L'Osservatore Romano” (Polishedition) 1 (1980) no. 9, p. 87.

${ }^{8}$ Giovanni Paolo II, Fraternita' che siallagra e prendre corpo. Al comitato economico e sociale della Comunita Europee, in: Insegnamenti di Giovanni Paolo II 1979, Vatican City 1979, vol. II, p. 679.

${ }^{9}$ P. de Laubier, La penseesociale de l'Eglisecatholique. Un ideal historique de Leon XIII a Jean Paul II, Fribourg 1984, p. 32.
} 
and even acquire a new splendour. The poor means are strictly bound up with the primacy of the spiritual. They are signs of the presence of the Holy Spirit in the history of mankind." ${ }^{\prime \prime}$

The Church aims to make it possible for the spirit of the Gospel to permeate the present world. John Paul II expressed this idea in his speech given when the ambassador of Colombia presented his diplomatic credentials. He said, among other things: "[The Church] is directed above all at developing man, especaially that part which is of the greatest value in him and the source of his eminent dignity: the image of God. An image which, in order to be authentic, must be projected in all fields - professional, family, cultural, social... - in which the human person grows and is ennobled, where his personal experience is enriched day by day, aimed at reaching a more and more just, united, and peaceful human community. ${ }^{11}$

Due to its role and competence, the Church is not identified in any way with any political system. ${ }^{12}$ As John Paul II said, if someone tried to identify the Church with any system or any political party, that person would show great ignorance of the essence of the Church. ${ }^{13}$ It is because the Church does not intend to direct current affairs or replace people responsible for governing in their respective fields. ${ }^{14}$ As has already been mentioned, the Church does not propose any political, economic or social model or even any third way between opposing systems because no system can fully live up to the dignity of man or the specific nature of a given nation. ${ }^{15}$

Because of that, the Church does not have and does not propose any particular "model" of social life and it is not associated with any political system which could serve as its own path, chosen among others. ${ }^{16}$ However, it does not mean

${ }^{10}$ Jan Paweł II, Przemówienie do Korpusu Dyplomatycznego, „Chrześcijanin w świecie” 12 (1980) no. 6(90), p. 86.

${ }^{11}$ Giovanni Paolo II, Le Credenziali del nuovo Ambasciatore di Colombia, in: Insegniamenti di Giovanni Paolo II 1979, Vatican City vol. II 1979, p. 831.

${ }^{12}$ Gaudium et spes, 76.

${ }^{13}$ Jan Paweł II, Wolność religijna jest owocem i gwarancją innych swobód obywatelskich. Spotkanie z Korpusem Dyplomatycznym w Meksyku, „L'Osservatore Romano” (Polishedition) 11 (1990) no. 6 (124), p. 18.

${ }^{14}$ Cent ansd'enseignementsociale de l'Eglise, Paris 1991, p. 43.

15 Jan Paweł II, Solidarni w budowaniu wspólnej ojczyzny. Powitanie w Bissan, „L'Osservatore Romano" (Polish edition) 11 (1990) no. 1 (120) p. 27.

${ }^{16}$ Sollicitudo rei socialis, 41. 
that the Church should not shape and encourage the faithful, in particular lay people, to become aware of their responsibility within the political community ${ }^{17}$ and to opt for solutions and models (if available) which make it possible for the inspiration of faith to be reflected in Catholic actions. ${ }^{18}$

A unique contribution which the Church makes to social matters is "strengthening the spiritual and moral foundation of society by doing everything in its power to make it possible for all actions taken for the common good to develop in harmony and in accordance with the guidelines and requirements of human and Christian ethics." ${ }^{\prime 19}$ This unique mission of the Church consists mostly in shaping the conscience, that is professing the moral law and its requirements, as well as revealing errors and attacks on the moral law and human dignity, which is the foundation of this law. ${ }^{20}$ The Church does it as part of its evangelization mission, which means that it serves the message of Christ in its eschatological dimension and in a specific context, depending on the historical situation. ${ }^{21}$ When the Church makes such efforts, it reminds every man about the truth of his dignity, as well as his basic rights and obligations, thereby calling for a life in which they are observed. ${ }^{22}$

\section{The need to respect every human}

The Church notices problems that the modern world is facing and is trying to address them. The Church focuses on human, regardless of their worldview, nationality or political system. Its teaching has always been based on Christian personalism. The point of departure for its teaching is human regarded as a person. Since the Church has adopted Christian ethical personalism, it sees the dignity of a human being as the foundation of moral obligation. Therefore,

${ }^{17}$ Gaudium et spes, 75.

${ }^{18}$ Kongregacja do spraw Wychowania Katolickiego, Wskazania dotyczące studiów i nauczania doktryny społecznej Kościoła w ramach formacji kapłańskiej, „L'Osservatore Romano” (Polishedition) 10 (1989) no. 7 (114), p. 17.

${ }^{19}$ Jan Paweł II, Nowy świat powstać musi w imię Boga i człowieka, op. cit., p. 11.

${ }^{20}$ Jan Paweł II, Przemówienie wygłoszone do członków Episkopatu Irlandzkiego, in: Jan Paweł II w Irlandii i Stanach Zjednoczonych, Warszawa 1981, p. 85.

${ }^{21}$ Jan Paweł II, Nowy świat powstać musi w imię Boga i człowieka, op. cit., p. 11.

${ }^{22}$ G. Cazzoni, Morale sociale, Casale Monferato 1991, p. 34. 
as a rational and free being, man is the first rule, the heart and soul of the comprehensive social teaching of the Church.

The beginning of mankind was the creation of man and woman, which crowned the divine act of creation. Man and woman are equally human beings, made in the image and likeness of God. ${ }^{23}$ Moreover, this image and likeness of God manifested by man and woman as spouses and parents is passed on to their offspring: "Be fruitful and increase in number; fill the earth and subdue it." ${ }^{24}$ God entrusts control over the Earth to mankind, all people, all men and women, who derive their dignity and vocation from their common beginning. ${ }^{25}$

From the very beginning, man has been made the lord of the Earth, the lord of the visible universe. However, the greatness of man is not limited to the fact that he subdues the Earth. ${ }^{26}$ His actual greatness lies in the fact that man was born out of God's own Being and made in the image and likeness of God. To a certain extent, an image reflects the essence of its Original. This is why man has no meaning without God. Man only makes sense in the world as the image and likeness of God. This also entails that it is impossible to reduce man solely to the visible world. Even though man functions in the world and comes from the world, he was born out of God. This is why man surpasses the whole visible world, surpasses it because he is closer to his divine original. Therefore, the special reason behind human dignity is man's vocation to participate in the life of God. From the very beginning, man has been invited to a conversation with God. "For man would not exist were he not created by God's love and constantly preserved by it; and he cannot live fully according to truth unless he freely acknowledges that love and devotes himself to His Creator." ${ }^{27}$

The truth about the dignity of man who was made in the image of God is not yet fully shown in the revealed truth found in the first chapters of the Bible. It was confirmed by John Paul II, who said: "Christ [is] the key to understanding that great and fundamental reality that is man. It is because man cannot be fully understood without Christ. Or rather: man is incapable of understanding himself fully without Christ. He cannot understand who he is, nor what his true dignity

${ }^{23}$ Jan Paweł II, List apostolski Mulieris dignitatem z okazji Roku Maryjnego o godności i powołaniu kobiety, „L'Osservatore Romano” (Polishedition) 8 (1988) no. 8 (105). p. 10.

${ }^{24}$ Gen. 1:28.

${ }^{25}$ Cf. Mulieris dignitatem, 6

${ }^{26}$ Gen. 1:28.

${ }^{27}$ Gaudium et spes, 19. 
is." ${ }^{28}$ Man remains a being that is incomprehensible even to himself and his life makes no sense "if he does not encounter love, if he does not experience it and make it his own, if he does not participate intimately in it."29 This is why Christ "fully reveals man to himself." ${ }^{30}$ In Christ, every man "finds again the greatness, dignity and value that belong to his humanity".

In the mystery of the Redemption, human becomes newly confirmed and, in a way, newly expressed and newly created. ${ }^{31}$ Therefore, in accordance to what John Paul II wrote in his first encyclical, if a man wants to "understand himself thoroughly - and not just in accordance with immediate, partial, often superficial or even illusory standards and measures of his being - he must with his unrest, uncertainty and even his weakness and sinfulness, with his life and death, draw near to Christ. He must, so to speak, enter into him with all his own self, he must 'appropriate' and assimilate the whole of the reality of the Incarnation and Redemption in order to find himself." ${ }^{\prime 2}$ John Paul II expressed the same thought when he said: "in Christ and through Christ man has acquired the full awareness of his dignity, of the heights to which he is raised, of the surpassing worth of his own humanity, and of the meaning of his existence." ${ }^{33}$

Jesus Christ was born into this world to reveal to mankind the truth about God. But not only that. He is most importantly the "Word" about man. ${ }^{34}$ Christ is the one who fully reveals the essence of humanity to mankind. Therefore, humanism reaches its fullest expression in Christ. Christ has revealed man to man by revealing God to him, by revealing the Father to him. It is impossible to express the full truth about man without bearing in mind that he comes from God, that he is the image and likeness of God Himself, that he was made and redeemed by God.

In the Church's view, human dignity and the knowledge of human rights constitute the basic criteria of humanity. "The measure of man is who he is, not

${ }^{28}$ Jan Paweł II, Podczas Mszy św. na Placu Zwycięstwa w Warszawie, in: Jan Paweł II, Nauczanie społeczne. Pielgrzymka do Polski 1979, Warszawa 1982, vol. I., p. 21.

${ }^{29}$ Redemptor hominis, 10.

${ }^{30}$ Redemptor hominis, 10.

${ }^{31}$ Redemptor hominis, 10.

${ }^{32}$ Redemptor hominis, 10.

${ }^{33}$ Redemptor hominis, 11.

${ }^{34}$ Redemptor hominis, 11; Cf. T. Ślipko, Godność osoby ludzkiej, „Ateneum Kapłańskie” 2474 (1970), p. 189. 
what he has. ${ }^{35}$ The sense of one's own dignity presupposes a whole set of requirements from oneself, one's behaviour and one's works. Human being is obliged to act in a way that is congruent with his dignity in all circumstances and areas of life. It also creates obligations and duties towards other people. At the same time, it is the source of rights. It is because every person is obliged to respect other people's dignity and at the same time entitled to have his or her dignity respected by others. As has already been mentioned, man has dignity due to the fact that he is a human being. Man was not granted dignity by the will of society or on the basis of a decision made by the state. He also did not win his dignity due to his social or state-related status. For this reason alone, neither society nor the state may or should deprive man of his ability to lead a life which corresponds to his dignity, nor limit this ability of man. ${ }^{36}$

Therefore, society and the state should respect human dignity. Every person has the right to expect that the society will respect their human dignity and let them live a life of dignity. However, it is not enough to refrain from taking actions which are contrary to the requirements derived from human dignity. It is also obligatory to take actions which will create conditions in which a person can live a life in accordance with their dignity. ${ }^{37}$

Catholic Social Teaching states that every person has valuein the policy of the state and in the entire system of modern civilization. Human dignity does not accept any other place for human being. Person has to be the "goal", not the "means"; the "subject"; the beginning, not a mere stop on the way to the finishing line in any agenda or in the organization of social life or statehood, in the sphere of science and culture, or in economic life. Respect for human and his dignity should be the basic criterium in settling all kinds of disputes, all such attempts should respect his fundamental rights. ${ }^{38}$

These rights belong to every person, they are common and inviolable, and no human being can waive them. Moreover, since it is not society that grants these rights, it may not limit them or take them away. ${ }^{39}$ This inalienability and inviolability is anchored in the human nature and ultimately in God, the

${ }^{35}$ Sollicitudo rei socialis, 28.

${ }^{36}$ Cf. T. Borutka, Problematyka moralno-społeczna w nauczaniu Jana Pawła II (wybrane zagadnienia), Kraków 1993, p. 13.

${ }^{37}$ Cf. T. Borutka, Nauczanie społeczne papieża Jana Pawła II, op. cit., p. 58.

${ }^{38}$ Cf. T. Borutka, Nauczanie społeczne papieża Jana Pawła II, op. cit., p. 58.

${ }^{39}$ Cf. R. Coste, L'Eglise et les droits de l'homme, Paris 1983, p. 53. 
Creator of human nature. Therefore, it is God who is their ultimate source. ${ }^{40}$ He is the one who inscribes these rights in human conscience and obliges man to respect them in every way possible. Moreover, God is the guarantor of all these human rights. ${ }^{41}$

Man is not granted his rights by the community. It is God who is their ultimate source and it is He who engraves human conscience with rights to oblige human dignity. He is also their guarantor. Therefore, all human rights have their common ontological foundation in God. Because of that, in his encyclical Centesimus annus John Paul II emphasized: "If there is no transcendent truth, in obedience to which man achieves his identity, then there is also no sure principle for guaranteeing fair relations between people." ${ }^{42}$ When law ceases to look for transcendent truth, it loses its stability and moral authority.

\section{The duty to take care of the family}

The family is the first and vital cell of society because "the Creator of all things has established conjugal society as the beginning and basis of human society." ${ }^{43}$ Marriage is a unique communion of two people which can serve as foundation to build a larger community. As John Paul II teaches that, the common good of spouses is love, faithfulness and honour they have for each other, as well as the durability of their relationship "until death do them part" 4 . This common good of two people bound by marriage is supposed to be passed on to their children. Therefore, the sacramental unity of spouses is consolidated and continues in the next generations.

It can be concluded that the family is a community of generations. However, nowadays there is a harmful tendency to limit the family to the ties between only two generations. It sometimes leads to a situation in which there is nobody with whom this common good could be shared, there is no way to multiply it. Due to the fact that the real family good appears when it is co-created and shared

${ }^{40}$ Cf. E. Filibeck, Les droits de l'homme l'enseignement de l'Eglise (de Jean XXIII a Jean Paul II), Vatican City 1992, p. 24.

\footnotetext{
${ }^{41}$ Veritatis splendor, 43.

${ }^{42}$ Veritatis splendor, 44.

${ }^{43}$ Gaudium et spes, 11.

${ }^{44}$ Veritatis splendor, 43.
} 
with others throughout the years, the current state of affairs brings about the suffering of individuals. This is because the more common good there is, the more it becomes our own, personal good. ${ }^{45}$

Man as a person is the resultant of the common good shared by families and mankind at large, individual communities and societies. In this context, it is necessary to mention the significant difference between the degree and the method. While each of us is the common good of our nation (as a compatriot) or the state (as a citizen), still we are the common good of the family in the most concrete way. This is why the family (much more than any other community) is an environment in which man can exist "for himself" through the unselfish gift of his own being. In this sense, the family remains a fundamental and irreplaceable community. It becomes the first and indispensable school of social life, an example and an impetus for wider social contacts based on respect, justice, dialogue and love. ${ }^{46}$

Therefore, as Synodal fathers reminded, the family is the cradle and the most effective tool that can be used in the humanization and personalization of society. It, fully and uniquely, contributes to shaping the world and makes life truly humane, in particular because it guards, maintains and passes on virtues and values. The Second Vatican Council stated that in the family, "generations come together and help each other grow wiser and harmonize rights of individuals with the requirements of social life." ${ }^{37}$

The family is a community of persons and the smallest social unit, so as such, it is the fundamental institution in the life of any society. The family is where future citizens are born, it is also a place where they are first taught about civil virtues, which determine proper development and growth of every society. By nature, the family is open to other families. To the best of their abilities and skills, families together should form the healthy fabric of the society. In other words, it is the unquestionable and primary foundation of any social life.

The family develops as a community of people which focuses on a human being, a concrete and unique person: a husband, a wife, a father, a mother, a son or a daughter. Children are the true fruit of love promised at the altar. What we are talking about is a family based on marriage, where man and woman exchange gifts of their own being and create a living environment in which a child

${ }^{45}$ Veritatis splendor, 17.

${ }^{46}$ Familiaris consortio, 42.

${ }^{47}$ Gaudium et spes, 52. 
can be born and develop its capabilities, gain the awareness of its own dignity and prepare themselves to face their own and unique vocation. ${ }^{48}$

The fundamental task of every family is to raise children, which means that paternity and maternity do not cease when the child is born. Upbringing in a family community is based mostly on the ability to gift each other with humanity. It is a bilateral process: parents give their mature humanity to the newly born child, whereas the child gives them all the novelty and freshness which he or she brings into this world. ${ }^{49}$

When it comes to shaping one's personality, social upbringing plays a vital role in this process. Its aim is to prepare a young person to live among other humans. There are multiple interconnections between an individual and society so upbringing needs to acknowledge social needs. It is because future citizens are born in the family and it is where they first learn about civil virtues that determine the development and growth of every society ${ }^{50}$. Therefore, the family is an irreplaceable value for the development of society. John Paul II believes that the family is the fundamental community in the widest sense because it has "formidable energies capable of taking man out of his anonymity, keeping him conscious of his personal dignity, enriching him with deep humanity and actively placing him, in his uniqueness and unrepeatability, within the fabric of society." ${ }^{51}$

Social upbringing should include such qualities as being kind to people, sensitivity to the common good, observing the principles of democracy, getting involved in the affairs of one's country, respecting social discipline, showing proactive attitude and initiative. It is about transferring certain notions, shaping feelings and developing attitudes which with time will turn a child into a committed member of society. This is why children should be brought up with the sense of freedom from material goods and accept a modest way of life, convinced that "a man's value is more in what he is than in what he has." ${ }^{52}$ Children should also grow in the ability to live their lives guided by justice and love.

John Paul II points out that one of the social tasks of the family is also to express opinions in the form of "a political intervention." ${ }^{53}$ Families should

\footnotetext{
${ }^{48}$ Centesimusannus, 39.

${ }^{49}$ Gratissimam sane, 16.

${ }^{50}$ Gratissimam sane, 42.

${ }^{51}$ Familiaris consortio, 43.

52 Gaudium et spes, 35.

${ }^{53}$ Familiaris consortio, 43.
} 
be the first to press state institutions to support and actively defend the rights and obligations of the family instead of merely complying with them. This is why families should be aware of their role as co-creators of the so-called "family policy" and bear the responsibility for transforming the whole society. Otherwise, they could themselves fall prey to the evil which they used to look at with indifference. ${ }^{54}$

\section{The state and the Church at the service of the family}

"At all stages of historical change, the family has always been the foundation of society and its most important institution. Thanks to blood ties and emotional, economic and cultural bonds, the family has guaranteed its members the sense of a collective identity and social security. The significance of the family in the process of supporting and satisfying people's most important needs is demonstrated by the fact that no institution has been created yet which would effectively replace the family, and those which have been created limit themselves to fulfilling intervening, corrective and compensatory functions, even when they operate under optimal conditions." ${ }^{55}$ The family fulfils the most important mental needs, whereas the traditional set of values passed on from generation to generation guarantees an uninterrupted transfer of material and emotional goods..$^{56}$

As has already been mentioned, the family is considered to be the smallest and at the same time the most important social group, made up of the spouses, children and relatives of each spouse. In the light of the law, the family is made up of a man and a woman lawfully joined in marriage and the children who are dependent on the spouses. The family comes into being naturally, as a result of fulfilling basic human needs, such as the need for love, safety, belonging and also the sexual needs. The family creates its own lifestyle, habits, means of expression and customs. The cultural assets of a family shape the personality of children in the process of socialization. The family passes their cultural

${ }^{54}$ Familiaris consortio, 44.

${ }^{55}$ E. Trafiałek, Rodzina jako obszar aktywności i źródło wsparcia w aktywnym starzeniu się, http://dspace.uni.lodz.pl:8080/xmlui/bitstream/handle/11089/4988/9.\%20Trafia\%C5\%82ek. pdf?sequence $=1$ (29.08.2015).

${ }^{56}$ D. Kuglin, Miłość fundamentem życia rodzinnego i chrześcijańskiego, „Sosnowieckie Studia Teologiczne" 9 (2009), p. 127. 
traditions on to next generations. Relationships between family members are the result of mutual ties of affection, but they are also shaped by legal regulations, customs, religion and tradition. ${ }^{57}$

Therefore, family cohesion is important for the society as a whole..$^{58}$ It is maintained through its internal forces, such as affection of family members for one another, the sense of security and mutual acceptance, the sense of personal worth, but also due to external pressure. When family bonds loosen or are lost, opinions can be heard, and rightfully so, that the country is losing its stability. This is confirmed by the fact that weak families result in a weak society, whereas strong families form a strong and durable society. ${ }^{59}$

Pope John Paul II emphasised the statement of the Second Vatican Council, that the family was "the first and vital cell of society". The Pope taught that "the family has vital and organic links with society, since it is its foundation and nourishes it continually through its role of service to life: it is in the family that citizens are born and in the family they find the first school of the social virtues that are the animating principle of the existence and development of society as such. Thus, far from being closed in itself, the family is by nature and vocation open to other families and to society, and undertakes its social role." ${ }^{30}$

Therefore, every country should be guided by the good of the family and should respect its rights. To achieve this, the state should have a social and family policy which favours a stable development of families. State authorities need to offer relevant support to single parents, families with disabled children, families which face external difficulties and large families. All actions taken by authorities and aimed at families should be based on the assistance principle: when a family is self-sufficient, it should not be helped out. It is because state interventions might be harmful. They would not be a sign of respect for families but rather of denying the family its rights. Therefore, the relationship between the state and the family should be based on autonomy and sovereignty, so that the family can be independent and self-sufficient in carrying out its social tasks. ${ }^{61}$

${ }^{57}$ K. Jeżyna, Małżeństwo i rodzina w kontekście przemian, „Sosnowieckie Studia Teologiczne” 9 (2009), p. 67.

${ }^{58}$ J. Mazur, Polityka przyjazna człowiekowi, Częstochowa 2018, p. 27.

${ }^{59}$ Gratissimam sane, 3.

${ }^{60}$ Familiaris consortio, 42.

${ }^{61}$ Cf. T. Borutka, Społeczne nauczanie Kościoła. Teoria i zastosowanie, Kraków 2004, p. 121. 
The state, which was established to ensure the proper functioning of society, is obliged to see the family as "a community governed by its own natural laws." This is why the state should not deprive the family of the tasks which it can carry out on its own. State authorities are obliged to do everything in their power to provide any help possible, such as economic, social, educational, political and cultural, which is necessary to make it possible for the family to function normally.

Since the very beginning, the Church has accompanied the Christian family on its path. The Christian family, which is in communion with the Church, participates in the earthly pilgrimage towards the full revelation and the fulfilment of the Kingdom of God. However, the ministerial care of the Church is not limited to Christian families. It covers all families, especially those which find themselves in difficult or abnormal situations. ${ }^{63}$ This activity should be progressive, which means that the Church should follow the family and accompany it at different stages of its formation and development. ${ }^{64}$

Remembering about the responsibility which every family needs to bear, Pope John Paul II has often addressed the family in his ardent appeals: "Family, become what you are. (...) Be what you have been ever since the beginning, according to the plan of God the Creator and the Redeemer. (...) Become a true communion of love, strong and durable, in which human life can be conceived and can develop." ${ }^{65}$

\section{Conclusion}

As part of its saving mission, the Church speaks up on social issues. The Church has done that ever since the beginning of its existence, but this process intensified by the end of the 19th century. All its efforts are aimed at one fundamental goal which is bringing individuals and the whole mankind to the unity with God. This is why this work goes beyond social and cultural spheres because it lies in the supernatural reality by nature.

${ }^{62}$ Dignitatis humanae, no. 5.

${ }^{63}$ Familiaris consortio, 65.

${ }^{64}$ Familiaris consortio, 17.

${ }^{65}$ Jan Paweł II, Dwie wielkie prawdy o rodzinie, „L'Osservatore Romano” (Polishedition) 3 (1982) no. 5 (29), p. 17. 
The mission of the Church consists in the introduction of evangelical principles into all areas of human existence. The Church, aware of its mission, expresses its solidarity with the whole of mankind, shares all its difficulties and accepts the rightful demands of those who fall victim to injustice as its own.

The key issues addressed in the social teaching of the Church are the respect for the dignity of a human being and his rights. It is due to this dignity that man becomes the centre of social life. Consequently, all social activity should serve man.

Due to the fact that it is through family life that man achieves the highest level of self-fulfilment, the Church defends this fundamental community, in which man is born and brought up. The family is a community of persons and the smallest social unit, and thus, it is the fundamental institution in the life of any society. Future citizens are born in the family, which becomes the place where they first learn about civil virtues that determine the development and growth of every society. By nature, the family opens up to other families and societies, thereby carrying out its social tasks.

Among the basic tasks of a Christian family there are also the church-related tasks. The aim of such a family is to build the Kingdom of God in history by taking part in the life and mission of the Church. The Church and the Christian family are connected thanks to the mutual bonds which make the family a "Church in miniature". It is a reflection and a historical revelation of the mystery of the Church.

\section{Bibliography}

Andre-Viencent P., La doctrine sociale de Jean Paul II, Paris 1983.

Antoncich R., Munarriz J. M., La doctrine socjale de l'Eglise, Paris 1992.

Bołoz W., Promocja osoby $w$ rodzinie, Warszawa 1998.

Borutka T., Kornecki T., Kroczek P., Rodzina fundamentem społeczeństwa.

Aspekt społeczno-prawny, Kraków 2018.

Borutka T., Nauczanie społeczne papieża Jana Pawła II, Kraków 1994.

Borutka T., Problematyka moralno-społeczna w nauczaniu Jana Pawła II (wybrane zagadnienia), Kraków 1993.

Borutka T., Społeczne nauczanie Kościoła. Teoria i zastosowanie, Kraków 2004.

Cazzoni G., Morale sociale, Casale Monferato 1991.

Cent ansd'enseignement sociale de l'Eglise, Paris 1991. 
Coste R., L'Eglise et les droits de l'homme, Paris 1983.

De Laubier P., La penseesociale de l'Eglise catholique. Un ideal historique de Leon XIII a Jean Paul II, Fribourg 1984.

Filibeck E., Les droits de l'homme l'enseignement de l'Eglise (de Jean XXIII a Jean Paul II), Vatican City 1992.

Giovanni Paolo II, Fraternitachesiallagra e prendrecorpo. Al comitato economico e sociale della Comunita Europee, in: Insegnamenti di Giovanni Paolo II 1979, Vatican City 1979, vol. II, p. 679-681.

Giovanni Paolo II, Le Credenziali del nuovoAmbasciatore di Colombia, in: Insegniamenti di Giovanni Paolo II 1979, Vatican City vol. II 1979, p. 831-832.

Jan Paweł II, Adhortacja apostolska o zadaniach rodziny chrześcijańskiej w świecie współczesnym „Familiaris consortio”, Vatican City 1981.

Jan Paweł II, Dwie wielkie prawdy o rodzinie, „L'Osservatore Romano” (Polishedition) 3(1982) no. 5(29), p. 15-17.

Jan Paweł II, Encyklika „Centesimus annus” w setnq rocznicę encykliki „Rerum novarum”, Vatical City 1991.

Jan Paweł II, Encyklika „Redemtor hominis”, Vatican City 1984.

Jan Paweł II, Encyklika” Sollicitudo rei socialis" z okazji dwudziestej rocznicy ogłoszenia „Populorum progressio", Vatican City 1988.

Jan Paweł II, Encyklika „Veritatis splendor” o niektórych podstawowych problemach nauczania moralnego Kościoła, Rome 1993.

Jan Paweł II, List apostolski 'Mulieris dignitatem' z okazji Roku Maryjnego o godności i powołaniu kobiety, „L'Osservatore Romano” (Polishedition) 8 (1988) no. 8 (105), p. 3-12.

Jan Paweł II, List do rodzin z okazji Roku Rodziny 1994, Vatican City 1994.

Jan Paweł II, Nowy świat powstać musi w imię Boga i człowieka. Do budowniczych społeczeństwa pluralistycznego, „L’Osservatore Romano” (Polishedition) 1 (1980) no. 9, p. 87-89.

Jan Paweł II, Podczas Mszy św. na Placu Zwycięstwa w Warszawie, in: Jan Paweł II, Nauczanie społeczne. Pielgrzymka do Polski 1979, Warszawa 1982, vol. I., p. 20-22.

Jan Paweł II, Przemówienie do Korpusu Dyplomatycznego, Chrześcijanin w świecie 12 (1980) no. 6 (90), p. 86-87.

Jan Paweł II, Przemówienie wygłoszone do członków Episkopatu Irlandzkiego, in: Jan Paweł II w Irlandii i Stanach Zjednoczonych. Warszawa 1981, p. 85-87.

Jan Paweł II, Solidarni w budowaniu wspólnej ojczyzny. Powitanie w Bissan, „L'Osservatore Romano" (Polish edition) 11 (1990) no. 1 (120), p. 26-27.

Jan Paweł II, Wolność religijna jest owocem i gwarancją innych swobód obywatelskich. Spotkanie z Korpusem Dyplomatycznym w Meksyku, „L'Osservatore Romano” (Polishedition) 11 (1990) no. 6 (124), p. 18.

Jeżyna K, Małżeństwo i rodzina w kontekście przemian, „Sosnowieckie Studia Teologiczne" 9 (2009), p. 62-71. 
Kongregacja do spraw Wychowania Katolickiego, Wskazania dotyczące studiów i nauczania doktryny społecznej Kościoła w ramach formacji kapłańskiej, „L’Osservatore Romano" (Polishedition) 10 (1989) no. 7 (114), p. 15-18.

Kuglin D., Miłość fundamentem życia rodzinnego i chrześcijańskiego, „Sosnowieckie Studia Teologiczne" 9 (2009), p. 127-139.

Mazur J., Polityka przyjazna człowiekowi, Częstochowa 2018.

Ślipko T., Godność osoby ludzkiej, „Ateneum Kapłańskie” 24.74(1970), p. 180-192.

Trafiałek E., Rodzina jako obszar aktywności i źródło wsparcia w aktywnym starzeniu się, http://dspace.uni.lodz.pl:8080/xmlui/bitstream/handle/11089/4988/9.\%20 Trafia\%C5\%82ek.pdf?sequence=1 (29.08.2015). 